\title{
Type and timing of first union formation in Québec and the rest of Canada: Continuity and change across the 1930-79 birth cohorts
}

\author{
Laura Wright ${ }^{1}$
}

\begin{abstract}
Trends in age at marriage have been well documented, but less is known about age at first union among recent cohorts of Canadians. Using the 2011 GSS, I document changes in the type and timing of first union formation among Canadians born over five decades, and examine how regional differences in partnering behaviours have changed over time. The trend away from entering marriage directly has continued among Canadians born in the 1970s, but Québec-Canada differences have narrowed. The trend towards later marriage has continued, but age at first union has not changed across the five cohorts under study.
\end{abstract}

Keywords: first union, marriage, cohabitation, Québec, Canada.

\section{Résumé}

Les tendances en ce qui a trait à l'âge au mariage ont été bien documentées, mais moins est connu quant à l'âge à la première union chez les dernières cohortes de Canadiens. À partir de données provenant de l'ESG de 2011, je documente les changements au niveau du type et du moment de la formation de premières unions auprès de Canadiens nés au cours de cinq décennies et j'examine en quelle mesure les différences régionales quant aux comportements liés au partenariat ont changé au fil du temps. La tendance à délaisser l'entrée directe au mariage a continué chez les Canadiens nés dans les années 1970, mais l'écart Québec-Canada a diminué. La tendance vers le mariage plus tardif a continué, mais l'âge à la première union n'a pas changé à travers les cinq cohortes à l'étude.

Mots-clés : Première union, mariage, union libre, Québec, Canada.

\section{Introduction}

Patterns of union formation have been changing in Canada and other Western nations over the last six decades. Past cohorts of Canadians have been delaying or forgoing marriage, and have increasingly formed nonmarital cohabitations, either as a step in the marriage process or as a union separate from marriage (e.g., Kerr et al. 2006; Le Bourdais and Lapierre-Adamczyk 2004). Differences between Québec and Canada in the type of first union, either marriage or cohabitation, widened between 1960 and 2000 as people in Québec became increasingly less likely to directly marry than other Canadians (Le Bourdais and Lapierre-Adamczyk 2004). Have these diverging trends continued, or has the gap narrowed with the rise of cohabitation in the rest of Canada among the newest birth cohorts? It is also less clear whether recent cohorts of Canadians are delaying all types of unions or whether the rise of cohabitation has offset delays of marriage. Studies of older Canadian cohorts suggest that median age at first partnership has not increased to the same extent as median age at first marriage (Ravanera et al. 2002). In other words, has age at first union increased along with age at first marriage in Canada, or do Canadians born in the 1970s continue to form their first romantic co-residential unions at the same age as their parents' and grandparents' generations?

1. Assistant Professor, Department of Sociology, University of Saskatchewan College of Arts \& Science, Room 1019 Arts, 9 Campus Drive, Saskatoon SK S7N 5A5; email: ldw960@mail.usask.ca. 
Understanding the changing partnership behaviours of recent cohorts of young Canadians is important because these changes are part of a much larger and significant transformation of family behaviours (Lesthaeghe 1995). There are also widespread institutional and individual implications for changes in partnership behaviours, including delayed and lower fertility, changes in union stability and the family contexts in which children are reared, the length of time spent as a dependent in the parental home, and intergenerational resource transfers (e.g., Bumpass et al. 1991; Kerr et al. 2006; Wu and Balakrishnan 1995). It is important to examine partnering behaviour in the culturally distinct region of Québec separately from the rest of Canada, because changes in partnering patterns have taken a different trajectory in the two regions (Hamplová et al. 2014; Laplante 2014). I seek to add to our broad understanding of family transformation and to provide stimulus for future research on the implications of these recent family changes.

Drawing on the 2011 General Social Survey, I update and extend past research on the changing patterns of union formation in Canada by examining how the type and timing of first union formation have changed across cohorts of Canadians born between 1930 and 1979. I examine changes across cohorts in the proportion of men and women choosing cohabitation rather than marriage as their first union type, changes in the proportion who are ever-partnered by age 35 , and changes in median age at first marriage and at first partnership. I examine these aspects of union formation by region to investigate whether differences between those in Québec and in the rest of Canada are continuing to grow or if the differences are narrowing as the rest of Canada continues on the trend toward increased cohabitation and declines in marriage.

\section{Background}

\section{Changes in union type}

There has been a significant transformation in demographic behaviour in Canada and other Western countries since about the 1960s, characterized in part by increased flexibility in union formation (Kerr et al. 2006; Lesthaeghe 1995). These changes are due to a combination of ideational shifts, including secularization and increased individualism, which created new norms regulating union formation, and structural changes, including the increased labour force participation of women (Lapierre-Adamczyk and Charvet 2000; Lesthaeghe 1995; Oppenheimer 1997).

Recent cohorts of Canadians have been delaying marriage compared to cohorts who came of age in the decades following WWII (e.g., Kerr et al. 2006), and an increasing proportion are forming non-marital cohabitations (Le Bourdais and Lapierre-Adamczyk 2004). In Canada, the median age at first marriage among women reached the lowest point in the 20th century in the 1960s, at around 21 years. Since then, the median age at first marriage has been increasing dramatically; in 2008, the average first-time Canadian bride was 29 years old (ESDC 2016). At the same time, the marriage rate in Canada has been decreasing, reaching only 4.4 marriages per 1,000 people in 2008 (Statistics Canada 2012).

The trend towards delayed or forgone marriage may be offset by increases in non-marital cohabitation, which has largely become an accepted and normalized part of the transition to partnership (Guzzo 2014; Settersten and Ray 2010). Cohabiting couples accounted for 6.3 per cent of co-residential Canadian couples in 1985, 10 per cent of couples in 1995 (Wu and Balakrishnan 1995), and nearly 17 per cent of Canadian couples in 2011 (Statistics Canada 2012). The percentage of Canadians who have ever cohabited has increased over time, as has the proportion of first unions that are non-marital cohabiting relationships. Using the 1984 Canadian Fertility Study, Rao (1990) found that 20.6 per cent of Canadian women cohabited outside of marriage with their first partner. Dumas and Belanger (1997) updated this research using the 1995 General Social Survey, and found that of the Canadians who entered a first union between 1990 and 1994, 57 per cent formed a cohabiting union. The most recent information to date on the proportion of Canadians starting conjugal life through cohabitation is derived from life table estimates using the 2001 Census, which finds that 53 per cent of Canadian women born in the 1970s can expect to cohabit as a first union (Le Bourdais and Lapierre-Adamczyk 2004).

This past work has shown that the prevalence of cohabitation is increasing in Canada, but because each study uses different samples, measures, and methodologies, it is difficult to explicitly examine changes over time. 
For instance, some studies have examined cohabiting unions formed in a given year (e.g., Dumas and Belanger 1997; Manning et al. 2014), some use cross-sectional data to determine how many Canadians are currently cohabiting (e.g., Wu and Balakrishnan 1995), and some estimate the proportion of people who have ever-cohabited, regardless of the order of the union (e.g., Brown et al. 2012; Bumpass and Lu 2000; Bumpass et al. 1991). In this paper, I use retrospective data to examine the differences in the type of first union across five birth cohorts of Canadians, and whether increases in cohabitation have offset declines in direct marriage.

\section{First union timing}

Median age at first marriage has been increasing in Canada, and the prevalence of cohabitation generally, and as a first union, has also increased. Yet, less is known about median age at first union when considering both marriage and cohabitation as possible first union types, especially in Canada. Manning et al. (2014) show that in the United States, median age at first union has not increased; Americans were partnering at roughly the same age between 1988 and 2010. They also show that the proportion of people who have ever partnered has also stayed relatively stable during this period.

Few studies have compared increases in the median age at marriage and median age at first union in Canada. Past studies of women born in the 1960s and earlier have found no significant changes in the median age at first partnership over time (Ravanera et al. 1998). However, since these studies, Canadians born in the 1970s have entered early adulthood and little is known about their partnering behaviour, despite many claims in the popular media that the new generations of Canadians are delaying or forgoing monogamous relationships. In this paper, I draw from the most recent available data to examine whether these trends have continued among the most recent Canadian cohort to enter into early adulthood.

\section{Regional differences}

The meaning and prevalence of cohabitation differ greatly between Québec and the rest of Canada (Hamplová et al. 2014). Quebecers tend to have more liberal perspectives on family issues than other Canadians (Wu 2000). Cohabitation has become a socially acceptable alternative to marriage in Québec, but is more likely to be a childless prelude to marriage in the rest of Canada (Hamplová et al. 2014; Kerr et al. 2006; Le Bourdais and Lapierre Adamcyk 2004). In 1981, only 7 per cent of couples in Québec were cohabiting, compared to 29.8 per cent in 2001 (Kerr et al. 2006), and 38 per cent in 2011 (Hamplová et al. 2014). There were also increases in the proportion of couples that were cohabiting in the rest of Canada during this period, but these increases were not as rapid or dramatic as those seen in Québec. In the rest of Canada, the prevalence of cohabitation increased from 5 per cent of couples in 1981 to 12 per cent in 2001 and only 14 per cent in 2011 (Hamplová et al. 2014).

The differences in union formation behaviour between people in Québec and the rest of Canada are far greater than the differences between the other Canadian provinces (Pollard and Wu 1998). In fact, the marriage rates of all of the Canadian provinces, excluding Québec, became more similar over the course of the 20th century (Wu and Balakrishnan 1995), reaching 608 per 1,000 women outside of Québec and only 373 per 1,000 women in Québec in 1994 (Pollard and Wu 1998). Moreover, the gap between the proportion of women in Québec and the rest of Canada expected to ever-marry has widened from the 1960s to the 2000s, with 40 per cent of Québec women expected to marry compared to 60 per cent of other Canadian women (Le Bourdais and Lapierre-Adamcyk 2004). In a recent study of how the competing risks of forming a first union through marriage or cohabitation have changed across cohorts of Canadians born between 1911 and 1971, Laplante (2014) found that the difference in the risks of cohabitation between French-speaking Québec Catholics and other groups of Canadians became dramatic starting in the 1951-60 birth cohort. He also finds that the risks of entering marriage have declined for all Canadians across cohorts, but that the category "French-speaking Québec Catholics and Atheists" has shown the greatest decline.

Differences in union formation behaviour between Québec and the rest of Canada have been best explained by referencing differences in normative cultures that are bounded by language, region, and religion (Laplante 2006, 2014). The demographic behaviour of French-speaking Catholic Québecois in particular diverged from other groups as the norms governing these behaviours diverged (Laplante 2006). Canadian researchers have argued that Québec experienced a "quiet revolution" in the 1960s whereby ideologies, values, and norms 
changed rapidly towards individualism, secularism, and gender equality, which led to the creation of a unique regime of union formation (Laplante 2014; Pollard and Wu 1998; Wu and Baer 1996).

It is less clear whether the differences in union formation patterns between Québec and the rest of Canada have continued to increase for those born in the 1970s, or whether there has been some convergence over time as cohabitation has become increasingly popular in non-Québec Canada. Laplante's (2014) study is the most recent to examine some of these questions; however, he does not explicitly examine changes over time in the proportion of ever-partnered, or patterns in median ages at first marriage and first union over time.

\section{Present study}

Past research provides insight into the union formation behaviours of Canadians, but relies on data from 2006 or earlier. In this paper, I add to our understanding of ongoing changes in union formation by using the most recent Canadian data available on cohabitation and marriage formation. By using retrospective data on union histories reported in the 2011 GSS, I am able to build on the approaches and findings of past research by analyzing the union formation patterns of birth cohorts rather than period changes in union formation. I am also able to analyze trends over a very wide range of birth cohorts born between 1930 and 1979, which will provide a better understanding of long-term trends in marriage and cohabitation.

\section{Research questions}

In this paper I address three research questions. First, how has the type of first union that Canadians form changed over time, and have the differences in the type of first union formed between those in Québec and the rest of Canada widened for those born in the 1970s? Second, is the decline in marriage over time being offset by increases in cohabitation for Canadians in Québec and other parts of Canada? Finally, has cohabitation been delayed to the same extent as marriage across cohorts of men and women in Québec and other parts of Canada, or has earlier cohabitation offset delays in marriage?

\section{Data}

I use the 2011 General Social Survey (GSS) to examine changes in union formation across five birth cohorts in Canada. The Canadian GSS is a cross-sectional survey conducted by Statistics Canada every year since 1985, with a specific thematic focus each year. The data for this study come from Cycle 25, the fifth and most recent GSS to focus on families. The GSS uses a stratified clustered sample and is representative of the non-institutionalized population aged 15 years or older living in the 10 Canadian provinces. It was conducted by computer-assisted telephone interviews between February and November 2011, and had a response rate of 65.8 per cent. The 2011 GSS is ideal for this study because it includes detailed retrospective information on both marriage and cohabitation histories for respondents born between 1911 and 1996, which allows for an examination of longterm trends in the changes of timing and type of union formation over many birth cohorts in Canada. These data are also the most recent available on Canadian families, and cover the most recent Canadian cohorts that have reached adulthood, born in the 1970s.

\section{Sample}

I restrict my analysis to respondents with complete information who were born after 1929 and before 1980. I exclude immigrants who migrated to Canada after age $15(\mathrm{n}=2,859)$, in order to maintain the comparability of the Québec population and the rest of Canada population, since patterns of immigration have changed dramatically in the last 100 years (Boyd and Vickers 2000), and to ensure that all of the partnering events that were included in the analyses occurred in Canada. These restrictions resulted in a sample of 15,941 respondents, reduced from the original sample of 22,435 . 


\section{Measures}

The GSS uses an inclusive measure of cohabitation and allows respondents to self-classify their unions as cohabitation regardless of the length of co-residence. The English version of the GSS asks respondents if they are, or have been, in a "common-law relationship, even if for less than one year." The French version asks the same questions but uses the term union libre. Québec follows the civil law tradition, whereas the rest of Canada is based on the common law tradition, which has resulted in different legal definitions of unions de libres in Québec and common law unions in the rest of the country (Beaujot et al. 2013). This measure of cohabitation is therefore inclusive of both definitions, used by both Anglophone and Francophone Canadians. I use the term cohabitation to encompass both common law unions formed outside of Québec and unions de libres in Québec.

I construct two separate dependent variables that reflect time to first union and time to first marriage. I use the age the respondent reported beginning their first union, either marriage or cohabitation, to construct the age at first partnership measure. I use respondents' reports of their age at their first marriage, regardless of any previous non-marital unions, to construct the age at first marriage measure. To construct my key independent variables, I group respondents by decade of birth, encompassing respondents born in the 1930s through the 1970s. I group these respondents into two categories based on their province of residence: those living in Québec and those living in the rest of Canada (ROC).

Finally, I control for several sociodemographic factors in the multivariate analyses. Language and religion have been found to predict union formation behaviours (e.g., Eggebeen and Dew 2009; Rao 1990), largely as markers of separate cultures, with different normative systems (Lapierre-Adamczyk and Charvet 2000; Laplante 2104). I classify the respondents into English-speakers, French-speakers, and others, based on the language they speak most frequently at home. I group respondents by religious affiliation, which includes categories for no religion, Catholic, Protestant, and other. Past research has also found that the more highly educated are more likely to marry (e.g., Sassler and Goldscheider 2004; Wu and Pollard 2000), and the less educated are more likely to cohabit, but that this association is weaker in Québec (Kerr et al. 2006). Highest educational attainment is coded as less than a high school diploma, a high school diploma, some postsecondary education including college, trades certificate or incomplete bachelor's degree, and bachelor's degree or higher. Lastly, individuals with divorced parents have been shown to be less likely to marry (Lapierre-Adamczyk and Charvet 2000), at least partly due to different attitudes towards marriage (Axinn and Thornton 1996). To control for these differences, I include an indicator for whether the respondent lived with two parents until at least age 15 years.

\section{Analytic strategy}

I begin by charting changes in the proportion of Canadian women and men, in Québec and in other parts of Canada, who enter their first union through marriage, through cohabitation, or who remain unpartnered by age 35. For these analyses I exclude respondents born in 1977 or later, because they had not yet reached age 35 at the time of the survey.

Next, I examine how changes across cohorts in the age at first union compare to changes in the age at first marriage, while controlling for other factors that influence the timing of union formation. To do this, I use discrete time logistic regression models to examine the risks of: 1) forming a first union and 2) entering legal marriage - separately for Québec and the ROC, and by sex, and include controls for language, religion, education, and childhood family structure. Respondents enter the risk set at age 15 and exit at age of first marriage/first union or the date of the survey, whichever occurs first. I created a person-period data file consisting of 245,941 person-years for the time to first marriage analyses, and 200,019 person-years for the time to first partnership analyses.

Unlike Cox-proportional hazards models, discrete time models require that the shape of the baseline hazard (the duration dependence) be specified (Box-Steffensmeier and Jones 2004; Jenkins 2005). Rather than assume a theoretical shape of the hazard function, I use a piecewise linear spline, with knots at each quintile of survival time, to model the duration dependence. ${ }^{2}$ Within each linear segment, the hazard rate is assumed to be constant

2. I specified the baseline hazard in several different ways, and a 5-point piecewise spline specification was the best characterization of the baseline hazard according to a variety of fit statistics, including the BIC and AIC (Singer and Willett 2003). 
but is allowed to vary across segments. This approach has the advantage of allowing the shape of the hazard function to be determined empirically without burdening the model with dummy variables for every unit of time (Singer and Willett 2003).

I then use these discrete time logistic regression models to estimate men's and women's median survival times to two events: (1) first marriage and (2) first partnership, by birth cohort and by region, while controlling for relevant sociodemographic variables. All estimates are derived using sample weights, to ensure they are representative of the population.

\section{Results}

\section{Description of the sample}

Table 1 presents characteristics of the full analytic sample. The left panel of the table provides the number of women in each birth cohort and the percentage of each cohort living in Québec and in other parts of Canada; the right panel displays the same information for men. Roughly 30 per cent of women and men born between 1930 and 1959 were living in Québec, and this proportion decreased slightly for those born between 1960 and 1979.

Table 1. Characteristics of the Sample 2011 General Social Survey Cycle 25 (Family), $n=15,941$

\begin{tabular}{cclccccc}
\hline \multicolumn{4}{c}{ Women } & \multicolumn{5}{c}{ Men } \\
\hline Birth cohort & $\mathrm{n}$ & Region & $\%$ & Birth cohort & $\mathrm{n}$ & Region & $\%$ \\
\hline $1930-39$ & 1,673 & ROC & 71.7 & $1930-39$ & 962 & ROC & 72.3 \\
& & Québec & 28.3 & & & Québec & 27.7 \\
$1940-49$ & 1,717 & ROC & 71.7 & $1940-49$ & 1,359 & ROC & 73.3 \\
& & Québec & 28.3 & & & Québec & 26.7 \\
$1950-59$ & 2,256 & ROC & 73.0 & $1950-59$ & 1,766 & ROC & 71.4 \\
& & Québec & 27.0 & & & Québec & 28.6 \\
$1960-69$ & \multirow{2}{*}{1,858} & ROC & 75.5 & $1960-69$ & 1,504 & ROC & 77.0 \\
& & Québec & 24.5 & & & Québec & 23.0 \\
$1970-79$ & \multirow{2}{*}{1,560} & ROC & 76.5 & $1970-79$ & 1,286 & ROC & 77.0 \\
& & Québec & 23.5 & & & Québec & 23.0 \\
\hline
\end{tabular}

Notes: Proportions are weighted to be representative of the Canadian population. "ROC" stands for "rest of Canada," and signifies respondents living in provinces outside of Québec.

\section{Proportion marrying, cohabiting, and never-partnered by age 35}

To examine changes over time in the type of first union that Canadians form, I plot the proportion of each cohort that entered into marriage directly, the proportion whose first union was a non-marital co-residential partnership, and the proportion unpartnered by age 35. Figures 1 and 2 display these proportions for women and men, respectively, by region. The solid lines represent the proportion whose first union was legal marriage, the dashed lines represent the proportion who cohabited with their first partner, and the dotted lines represent the proportion who had never partnered by age 35. The grey lines show the trends for those living in Québec, and the black lines show the trends for those in the rest of Canada (ROC). In light grey, I provide the 95\% confidence intervals derived from two-sample tests of equality of proportions for each point estimate.

Figure 1 shows that women in Québec are less likely to enter into direct marriage than women in the ROC across all birth cohorts, and the decline in the proportion entering marriage directly across birth cohorts is more dramatic in Québec than for women in the ROC. Approximately 87 per cent of women living in Québec born in the 1930s entered marriage directly, compared to approximately 93 per cent of their counterparts living in the ROC. The regional difference in the propensity to enter marriage directly is similar among women born in the 1940s. However, there is no significant regional difference in the proportion of women who cohabit with their 


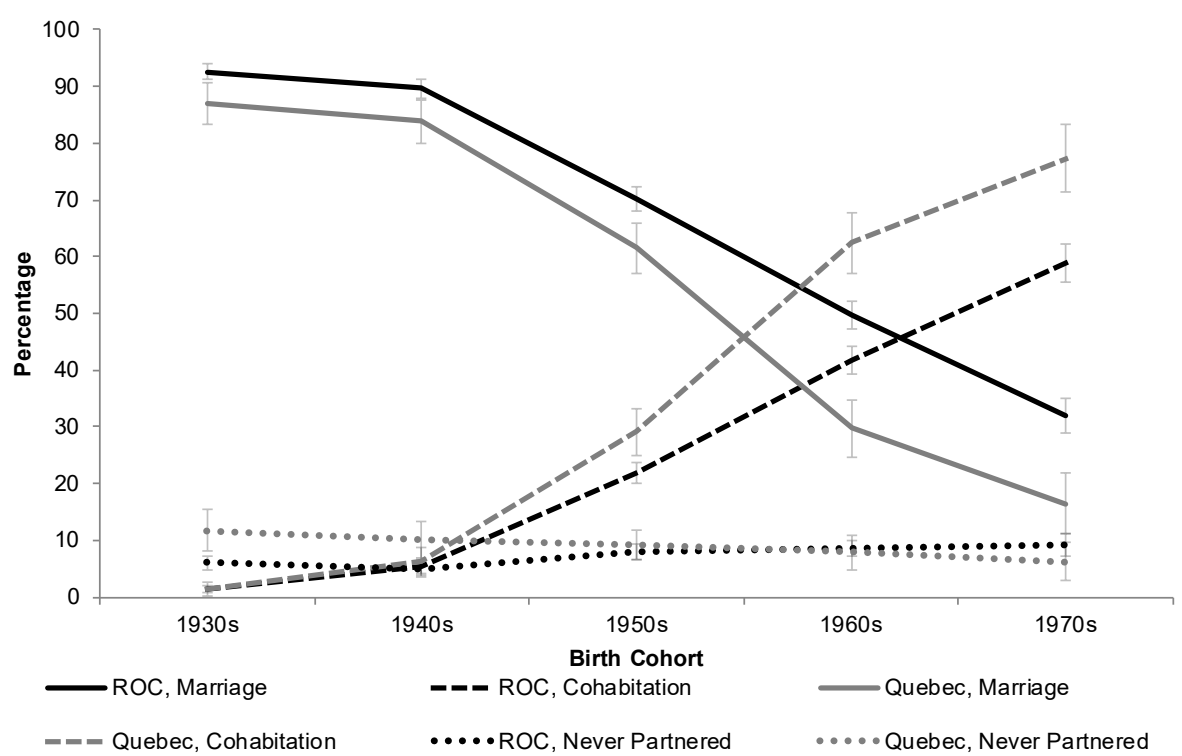

Figure 1. Percentage of women whose first union was marriage, cohabitation, and who never-partnered by age 35, by region, 1930s-70s birth cohorts, with 95\% confidence intervals

first partner in these early birth cohorts; in both regions, fewer than 2 per cent of women born in the 1930s and 1940s entered their first unions through cohabitation. The difference in these cohorts is that women in Québec were less likely to be in any type of partnership than those in the ROC (10-12 per cent of those in Québec compared to 5-6 per cent of those in the ROC).

Regional differences in the proportion of women entering conjugal life through cohabitation become significant in the 1950s birth cohort, and increase among those born in the 1960s (Figure 1). Approximately 22 per cent of women in the ROC born in the 1950s cohabited with their first partner, compared to 29 per cent of women in Québec. By the 1960s birth cohort, the majority of women in Québec cohabited as their first union (62 per cent), as did a large minority of women in the ROC (42 per cent). The trend toward cohabitation and away from direct marriage continues for women born in the 1970s; however, the regional divergence in first union type that had been increasing since the 1940s birth cohort appears to have stalled among this birth cohort. Women in Québec

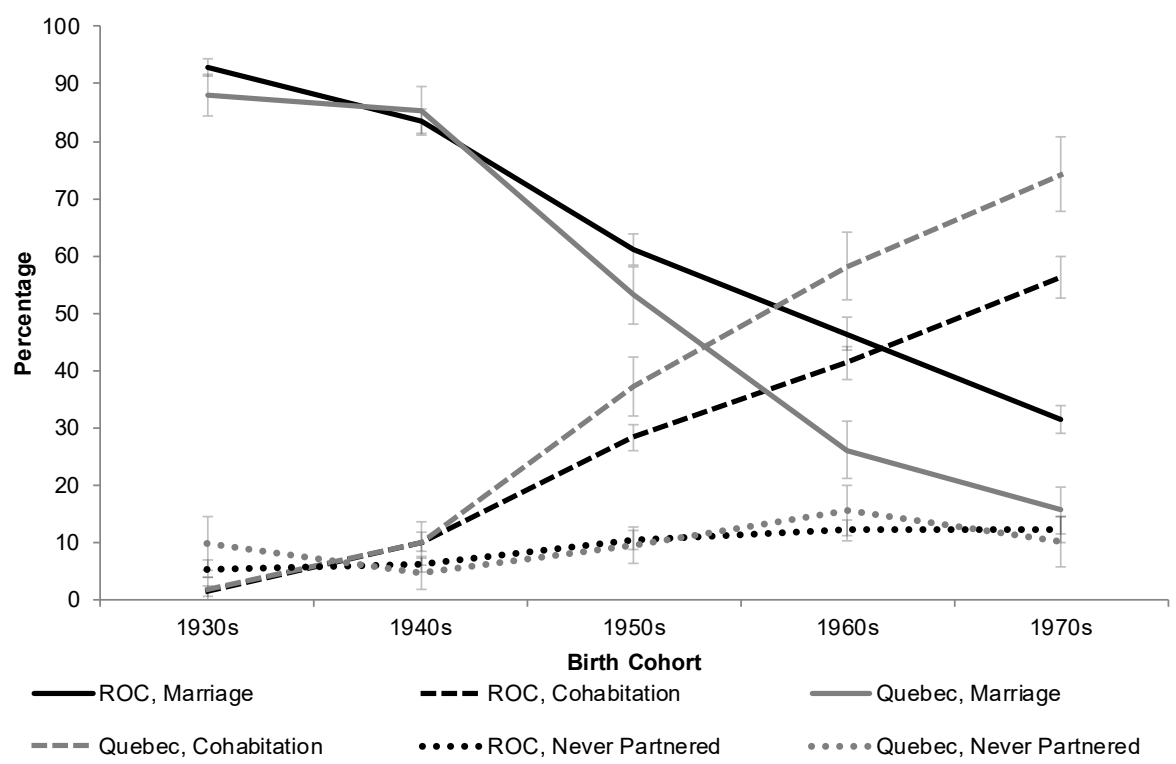

Figure 2. Percentage of men whose first union was marriage, cohabitation and who never-partnered by age 35, by region, 1930s-70s birth cohorts, with 95\% confidence intervals 
born in the 1970s continue to be more likely to cohabit with their first partner than their counterparts born in the ROC, but the difference is smaller than in the previous birth cohort. Approximately 16 per cent of women in Québec born in the 1970s entered directly into marriage, compared to roughly 32 per cent of women in the ROC, which indicates that large regional differences remain despite the stalled divergence over time.

The proportion of women never-partnered by age 35 has stayed relatively stable across the birth cohorts of women born in the ROC, increasing slightly, albeit statistically insignificantly, from 5-6 per cent of those born in the 1930s and 40s to 8-9 per cent of those born in the 1950s, 60s, and 70s. There are also no statistically significant changes in the proportion never-partnered by age 35 across birth cohorts among women in Québec, which decreased slightly, from 10-11 per cent of those born in the 1930s and 40s to 6-7 per cent of those born in the 1960s and 70s.

The proportions of men who enter directly into marriage, who cohabit with their first partner, and who remained unpartnered by age 35 are shown in Figure 2. The overall and region-specific patterns in men's first union types are similar to those found for women; however, those born in the 1940s and 50s were slightly less likely to enter directly into marriage than their female counterparts. Approximately 59, 44, and 28 per cent of men living in the ROC born in the 1950s, 60s, and 70s, respectively, entered directly into marriage with their first partner, compared to 53, 26, and 16 per cent of their counterparts in Québec. Regional differences in the proportion of men entering conjugal life through cohabitation first appear in the 1950s birth cohort, which is the same pattern as seen for women. As was the case for women, the difference between men born in Québec and the ROC in the propensity to marry directly also increases between the 1940s, 50s, and 60s birth cohorts, but the regional divergence slows among the most recent birth cohort, who were born in the 1970s and came of age in the 1990s, albeit to a lesser degree than is the case for women. The proportion of men born in the ROC who never partnered by age 35 has increased across birth cohorts, ranging from approximately 5-6 per cent in the early cohorts to around 12 per cent in the most recent birth cohort of men born in the 1970s, and the difference between the those born in the 1930s and 40s and those born after is statistically significant. Among Québec-born men however, there are no statistically significant changes in the proportion never-partnered by age 35 across the birth cohorts (Figure 2).

\section{Age at first marriage vs. age at first union across cohorts}

Next, I examine cohort differences in the risk of entering first marriage, and the risk of entering a first union of any kind, in order to predict the timing of union formation. Tables 2 and 3 present odds ratios from discrete-time logistic regression models for women and men, respectively. The left panel of each table displays models predicting first marriage separately by region, and the right panel displays the same for first union.

The parameter estimates describing the duration dependence shown in the bottom of Tables 2 and 3 represent the fitted baseline hazard function (transformed into odds ratios) (Jenkins 2005; Singer and Willett 2003). The baseline represents English-speaking respondents born in the 1950s, who have no religious affiliation, graduated high school, and who lived with both parents until at least age 15. Across all models, the odds of experiencing a partnering event peak in the second quintile of survival time (ages 18-21 years for the marriage models and 18-19 years for the first-union models). After this point, the baseline hazard decreases over survival time.

The marriage models for women in the left panel of Table 2 show that there are significant differences in the odds of marriage across birth cohorts for both women in Québec and women in the ROC. Women in Québec born in the 1970s have 3.2 times lower odds of marriage compared to those born in the 1950s (0.31 odds ratio). For women in the ROC, the difference is smaller; those born in the 1970s have 1.89 times lower odds of marriage compared to the 1950s birth cohort. Francophone women in Québec have lower odds of marriage than Anglophones in Québec, but there are no differences by language in the ROC. In the ROC, any religious affiliation is associated with higher odds of marriage, but Protestants have the largest difference, with odds of marriage 1.24 times that of women with no religious affiliation. In Québec, Protestant and other religious groups are more likely to marry, but Catholics are not statistically different in their odds of marriage compared to the unaffiliated. In both regions of Canada, women with higher levels of education have lower odds of marriage. Women with a bachelor's degree or higher have lower odds of marriage than the 
high school educated (1.56 times lower for women in Québec, and 1.85 times lower for women in the ROC). Finally, women who grew up without two parents in the home had 1.18 times lower odds of marriage than respondents who lived with two parents, regardless of region.

Table 2. Odds ratios from discrete-time logistic regression models predicting entry into first marriage and first partnership, women,

\begin{tabular}{|c|c|c|c|c|}
\hline \multirow[b]{2}{*}{ Model } & \multicolumn{2}{|c|}{ First marriage } & \multicolumn{2}{|c|}{ First union } \\
\hline & Que & $\mathrm{ROC}$ & Que & $\mathrm{ROC}$ \\
\hline \multicolumn{5}{|l|}{ Birth cohort (1950s) } \\
\hline $1930 \mathrm{~s}$ & 1.10 & $1.12+$ & $0.69 * * *$ & $0.84 * *$ \\
\hline $1940 \mathrm{~s}$ & $1.29 * *$ & $1.39 * * *$ & 0.88 & $1.13^{*}$ \\
\hline $1960 \mathrm{~s}$ & $0.64 * * *$ & $0.67 * * *$ & 1.04 & $0.79 * * *$ \\
\hline $1970 \mathrm{~s}$ & $0.31 * * *$ & $0.53 * * *$ & 1.08 & $0.73 * * *$ \\
\hline \multicolumn{5}{|l|}{ Language (English) } \\
\hline French & $0.84+$ & 1.03 & $1.30^{*}$ & 1.14 \\
\hline Other & $0.96+$ & 0.98 & 0.94 & 0.99 \\
\hline \multicolumn{5}{|l|}{ Religion (None) } \\
\hline Catholic & 1.14 & $1.13 *$ & 0.97 & $0.87 * *$ \\
\hline Protestant & $1.47+$ & $1.24 * * *$ & 1.12 & 0.95 \\
\hline Other & $1.83+$ & $1.22 *$ & 1.14 & 0.88 \\
\hline \multicolumn{5}{|l|}{ Education (High School) } \\
\hline Less than H.S. & 1.10 & 1.01 & 1.04 & $1.17 *$ \\
\hline PSE less than BA & 0.88 & $0.76^{* * *}$ & 0.84 & $0.81 * * *$ \\
\hline BA or higher & $0.64 * * *$ & $0.54 * * *$ & $0.62 * * *$ & $0.50 * * *$ \\
\hline \multicolumn{5}{|c|}{ Family structure ( 2 parents) } \\
\hline Other family type & $0.85+$ & $0.84 * * *$ & 1.02 & $1.11^{*}$ \\
\hline \multicolumn{5}{|l|}{ Duration dependency } \\
\hline Marriage & & & & \\
\hline $15-17$ & $0.76 * * *$ & $0.80 * * *$ & $0.76 * * *$ & $0.80 * * *$ \\
\hline $18-21$ & $2.12 * * *$ & $1.80 * * *$ & $3.64 * * *$ & $2.84 * * *$ \\
\hline $22-25$ & 0.98 & 1.02 & $1.27 * * *$ & $1.18^{* * *}$ \\
\hline $26-34$ & $0.85 * * *$ & $0.92 * * *$ & $0.88 * * *$ & $0.95 * * *$ \\
\hline $30+$ & $0.88^{* * *}$ & $0.86^{* * *}$ & $0.88 * * *$ & $0.87 * * *$ \\
\hline
\end{tabular}

Note: *** $\mathrm{p}<0.001 ; * * \mathrm{p}<0.01 ; * \mathrm{p}<0.05 ;+\mathrm{p}<0.10$

Quintiles of survival time to first marriage and first partnership are used to model the duration dependency; these coefficients form the baseline hazard.

Reference categories are in parentheses.

Source: 2011 General Social Survey (Cycle 25).

The right panel of Table 2 shows the estimates from the first-union models, which treat either marriage or cohabitation, whichever occurs earlier, as a first partnering event. Cohort differences in the odds of partnering are far smaller than differences in the odds of marriage, and are statistically insignificant for women in Québec (except women in Québec born in the 1930s, who are 1.45 times less likely to form any sort of partnership compared to those born in the 1950s). Cohort differences in the ROC are statistically significant, but women born in the 1970s have only 1.37 times lower odds of partnering than the 1950s birth cohort (compared to 1.89 times lower in the case of marriage). Francophone women in Québec have odds of partnering that are 1.3 times higher than Anglophone women in Québec; and, similar to the models of marriage, these are the only significant language differences. The only statistically significant difference by religious affiliation is for Catholic women in the ROC, who have 1.15 times lower odds of partnering than the unaffiliated. Educational patterns in the risks of partnership are very similar to those for risks of marriage: the more highly educated have lower odds of partnering. Finally, living in a home without two parents during childhood is associated with 1.11 times higher odds of partnering for women in the ROC, but there are no differences by childhood family structure for women in Québec. 
Table 3. Odds ratios from discrete-time logistic regression models predicting entry into first marriage and first partnership, men, $n=6,877$

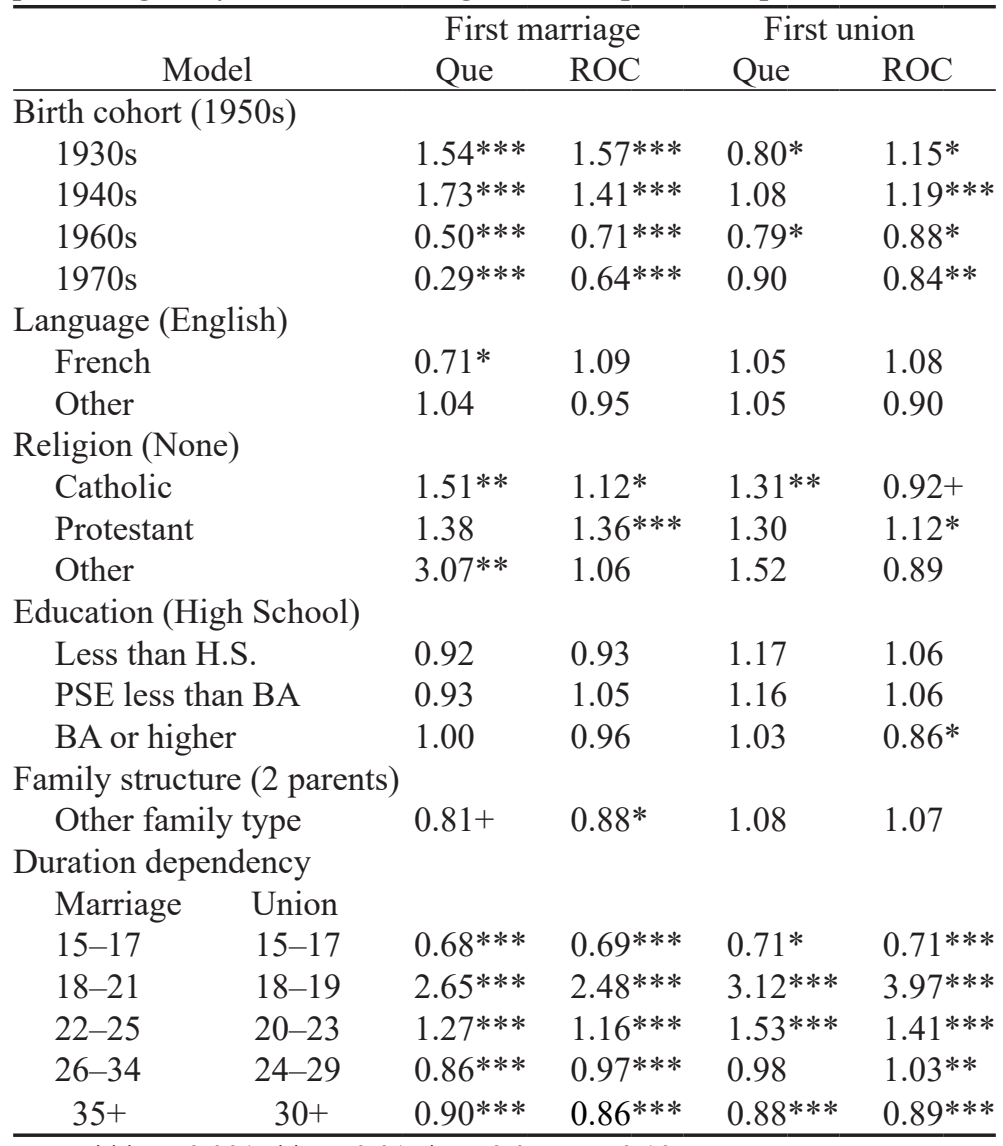

Note: $* * * \mathrm{p}<0.001 ; * * \mathrm{p}<0.01 ; * \mathrm{p}<0.05 ;+\mathrm{p}<0.10$

Quintiles of survival time to first marriage and first partnership are used to model the duration dependency; these coefficients form the baseline hazard. Reference categories are in parentheses.

Source: 2011 General Social Survey (Cycle 25).

Table 3 presents the same discrete-time logistic regression models predicting marriage and partnership, by region, for men. The patterns for men's odds of marriage are largely the same as for women, but there are a few exceptions (left panel of Table 3). Catholic men in Québec have 1.51 times higher odds of marrying compared to those with no religious affiliation, and there are no significant educational differences in the odds of marriage for men, in either Québec or the ROC. The right panel of Table 3 presents the models for partnering, either marriage or cohabitation. Unlike for women in Québec, there is no statistically significant difference between the odds of partnering for Francophone men compared to Anglophone men in Québec. There are also differences by religious affiliation for men: Catholic men in Québec have 1.31 times higher odds of partnering than the unaffiliated. Catholic men in the ROC however, have 1.09 times lower odds of partnering, and Protestant men have 1.12 higher odds than those with no religious affiliation. There are also few educational differences in the odds of first union for men. The only statistically significant difference is for men in the ROC who have a bachelor's degree or higher, who have odds of partnering 1.16 lower than those with a high school diploma. Family structure in childhood does not appear to be associated with the risks of partnership for men.

Median survival time to first marriage and to first union for each cohort, by region, regardless of union type and controlling for other sociodemographic factors, are presented in the top panel (for women) and bottom panel (for men) of Table 4. The estimates in these tables are derived from the discrete-time logistic regression models in Tables 2 and 3. The age at which half of the women in the ROC are estimated to form a first marriage increased, from a low of 21.2 years for women born in the 1930s to a high of 26.1 years for women born in the 1970s (top panel of Table 4). Over this time, women in the ROC have delayed their first marriage by five years, 
Table 4. Fitted median times to first marriage and first union, across birth cohorts, by place of residence.

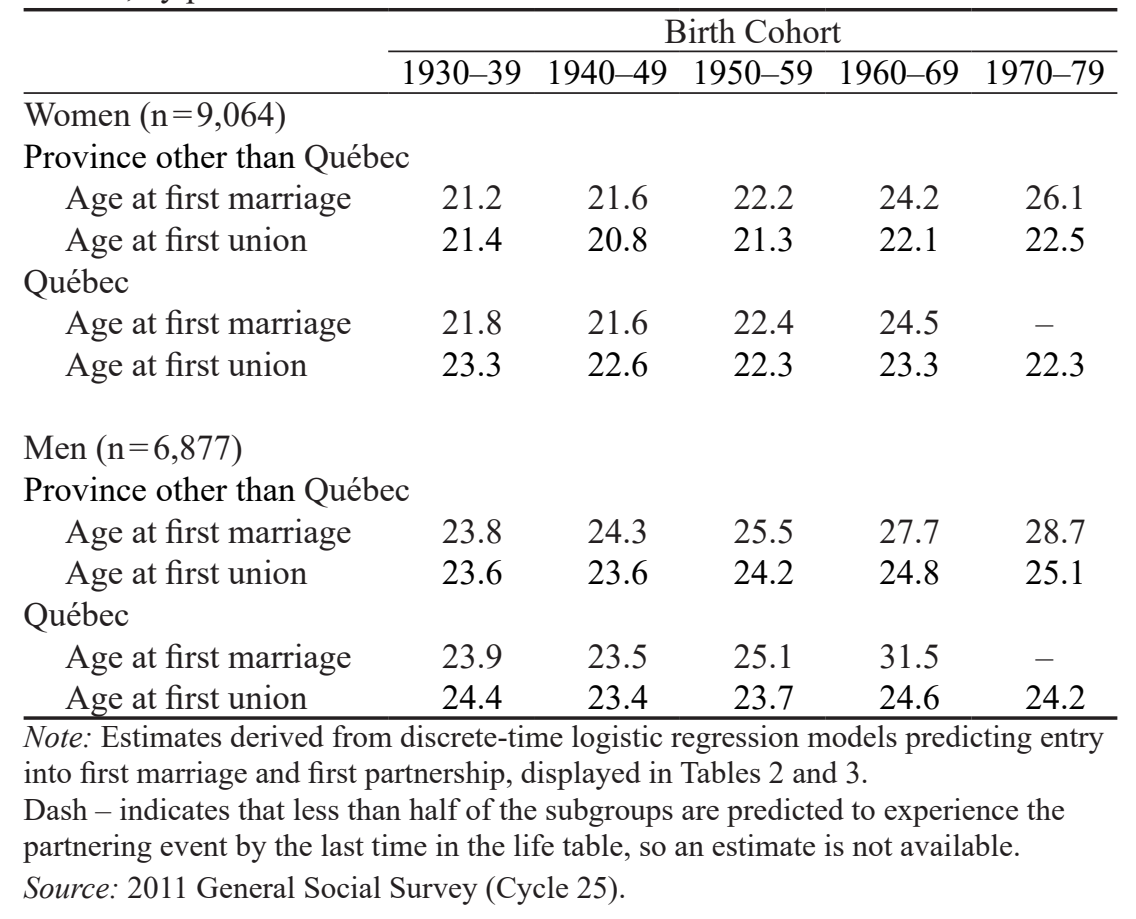

even after controlling for differences in education, religion, childhood family structure, and the other controls in Table 2. However, Canadian women are not delaying partnering to nearly the same degree as marriage. Half of all women in the ROC born in the 1930s are estimated to form their first union by age 21.4, and among those born in the 1970s, half are estimated to form their first union by age 22.5-a difference of only 1.1 years. Typical ages at first marriage and first union corresponded quite closely in the earlier cohorts, in which marriage was by far the most likely way to form a first partnership. These ages began to diverge across the cohorts, especially for the 1960s birth cohort, which entered adulthood in the 1980s, as cohabitation became an increasingly common way to form a first union.

These trends are even more pronounced among women in Québec. Half of the women in Québec born in the 1930s, 40s, and 50s are estimated to have married between age 21.6 and 22.4 years. By the 1960s birth cohort, the estimated median survival time to first marriage increased to 24.5 years. The median survival time to first marriage could not be estimated for Québec women born in 1970 or, later because less than 50 per cent of this birth cohort is predicted to be married by age 40 years, indicating a continued delaying or forgoing of marriage among this cohort. Median estimated survival time to first partnership, however, has stayed remarkably stable across the cohorts of women in Québec, even with controls. The estimated median age at first union varies by only 1 year (ranging from age 22.3 years for those born in the 1950 s and 70 s to 23.3 years for those born in the 1930s and 60s). The same patterns in fitted median survival times to first marriage and first partnership can be seen for men in the bottom panel of Table 2, but men tend to enter marriage and form their first partnerships 2-3 years later than their female counterparts.

\section{Discussion and conclusion}

The rise in cohabitation and delaying of marriage are two of the most important changes in union formation patterns that have occurred in Canada over the last 50 years. In this paper, I have documented these wellknown known trends in older Canadian birth cohorts, and have updated previous analyses by using the most recent Canadian data available to examine the most recent cohorts of Canadians. I have also documented longterm trends in median age at first union across birth cohorts, which has been far less studied than median age at 
marriage. The results contribute to our understanding of the way in which increases in cohabitation have offset the decline and delay of marriage as a first partnership for the newest cohort of Canadians entering adulthood.

Consistent with past research (e.g., Laplante 2014; Le Bourdais and Lapierre-Adamczyk 2004), I found that across birth cohorts, an increasing number of Canadian men and women are choosing to form non-marital cohabiting unions rather than marriages as they enter conjugal life. Marriage as a first partnership type has continued to decline among the most recent birth cohorts of Canadians. The decline in the proportion of Canadians whose first union was marriage, however, has been largely offset by an increase in the formation of cohabiting relationships. The proportion of women and men in Québec and women in the ROC forming any type of union by age 35 years has remained stable over the birth cohorts. Among the men in other parts of Canada, however, increases in the proportion forming cohabiting unions have not kept pace with decreases in marriage formation for the most recent birth cohorts, leading to a slight increase in the proportion never-partnered by age 35 across the birth cohorts.

I find that the trend towards delayed marriage in Canada, which began in earnest among those born in the 1960s, who came of age in the 1980s, has continued for both men and women born in the 1970s. The typical age at first partnership, when both marriage and cohabitation are considered, however, has not changed much over the course of the 50 years under study. This is further evidence that the rise in cohabiting unions has indeed offset the delays in marriage. Canadians born in the 1970s continue to form their first unions at approximately the same age as their parents' and grandparents' generations, but the type of first union they form is different.

I also examined differences in first union formation behaviours between Canadians in Québec and the ROC to determine if the disparity in the preferred type of first union that has been growing since the 1940s birth cohort has continued among the most recent birth cohorts, who came of age in the 1990s. Consistent with past research (e.g., Laplante 2014; Le Bourdais and Lapierre-Adamczyk 2004), I found that the pattern of increased preference for cohabitation and decreased preference for marriage as a first union type is more dramatic among men and women in Québec and less dramatic for those in other parts of Canada. Across all cohorts, men and women in Québec are less likely to marry their first partner. However, the this trend toward an ever-decreasing proportion of marriages as first union has slowed for the most recent cohort in Québec, while it continued for the most recent cohort in the rest of Canada, especially for men. This means that the difference in choice of first union type between the Quebecers and other Canadians, which has been growing since at least the 1940s birth cohort, has stabilized among the youngest Canadians included in this study. This provides some evidence that the meaning and place of cohabitation in the union formation process in the rest of Canada may be becoming more like that found in Québec. Further examination of the characteristics and outcomes of cohabiting unions of recent birth cohorts in the two regions is needed to fully address this question.

Québec also displays a more dramatic pattern of change in age at first marriage and first partnership over time than the ROC. Age at first marriage has increased to a greater extent in Québec, but age at first partnership continues to be younger in Québec than in the rest of Canada. Quebecers are increasingly moving away from marriage, but not only are they still partnering, in more recent birth cohorts they are doing so earlier than other Canadians.

The picture that these results reveal about how the role of cohabitation differs in Québec and the rest of Canada is clear. On the one hand, Canadians outside of Québec seem to be catching up to those in Québec in terms of their propensity to start their conjugal lives through cohabitation. This indicates that cohabitation as a first union type is perhaps on its way to near universality among non-immigrant Canadians. However, this says little about whether these first cohabiting unions, or cohabiting unions in general, have replaced marriage or whether they are better conceived as a stage in the marriage process. The large differences in age at first marriage do, however, provide some evidence that marriage is still much more common among men and women in other parts of Canada than it is among those in Québec who are delaying and increasingly forgoing marriage altogether.

This study has many advantages, including the use of the most recent available Canadian data on union formation, and the inclusion of a wide range of birth cohorts of Canadians born between 1930 and 1979. However, it is not without its limitations. One limitation is that it excludes other determinants of type of first union choice and timing of first union that have been shown to be important in past research, including the conception, birth, and presence of children, income, and work status (e.g., Eggebeen and Dew 2009; Kerr et al. 
2006; Rao 1990). The 2011 GSS includes retrospective information about fertility and work histories, so future work could include these measures to further the results of this study. Unfortunately, the data do not include time-varying measures of income, so a different data source is necessary to directly examine hypotheses about association between delayed or forgone marriage and income.

A second limitation is the reliance on retrospective data regarding union histories. As with all retrospective data, these data are subject to recall and mortality biases (Hassan 2005). Recall bias is likely less of a problem when studying significant life course events, such as marriage and cohabitation, that this paper addresses, than it may be for more mundane or more frequently occurring events (Freedman et al. 1988). Past research has also shown that many couples "slide" into cohabitation (Manning and Smock 2005; Stanley et al. 2006), so assessing the exact timing of cohabitation union start may be difficult. This is not a major limitation in this study, because I use age at union start, which is easier to determine than the specific date that the union began. The mortality bias introduced by the data is likely more serious for the earlier birth cohorts under examination. Respondents born in the 1930s and 40s were between 62 and 81 years old at the time of the survey, and only individuals who survived to this age could be sampled. The median survival time to first marriage for these birth cohorts found in this study corresponds closely with past studies of these cohorts (e.g., Pollard and Wu 1998; Rao 1990; Ravanera et al. 2002), so it appears that the mortality bias is not a large concern.

Despite its limitations, this paper contributes to our understanding of the first partnering behaviours of recent cohorts of Canadians. The widespread changes in union formation that have occurred in Canada over the last 50 years are continuing among the newest generation of Canadians to come of age. Cohabitation is increasingly becoming the most common way to form a first union, and marriage is being delayed even longer and is increasingly forgone, especially in Québec. Yet the more things change, the more they seem to stay the same. Namely, the proportion of Canadians that have formed any type of union by age 35 has not declined along with the decline in marriage for those in Québec, or women in the ROC, and has declined only marginally for men in the ROC. The typical age at first union has stayed remarkably stable across the cohorts of Canadians born between 1930 and 1979. However, the changes in the types of unions that Canadians are forming may have further implications. For instance, if cohabiting relationships continue to be less stable than marriages (Bumpass and $\mathrm{Lu} \mathrm{2000),} \mathrm{and} \mathrm{if} \mathrm{unions} \mathrm{formed} \mathrm{at} \mathrm{younger} \mathrm{ages} \mathrm{are} \mathrm{more} \mathrm{likely} \mathrm{to} \mathrm{dissolve,} \mathrm{we} \mathrm{can} \mathrm{expect} \mathrm{that} \mathrm{more} \mathrm{recent}$ cohorts of Canadians will experience more turbulent partnership trajectories than past generations. This paper serves as the foundation for future studies on the explanations and consequences of the partnership behaviours of Canadians born after the 1970s.

\section{Acknowledgements}

I am grateful to Rachel Margolis, Lisa Strohschein, and the anonymous reviewers for their valuable comments on this manuscript, and to Jean-François Nault for translating the abstract into French. This research was supported by the Social Sciences and Humanities Research Council of Canada.

\section{References}

Axinn, W.G., and A. Thornton. 1996. The influence of parents' marital dissolutions on children's attitudes toward family formation. Demography 33(1):66-81.

Beaujot, R., C.J. Du, and Z. Ravanera. 2013. Family policies in Québec and the rest of Canada: Implications for fertility, child-care, women's paid work, and child development indicators. Canadian Public Policy 39(2):221-39.

Box-Steffensmeier, J.M., and B.S. Jones. 2004. Event History Modeling: A Guide for Social Scientists. New York: Cambridge University Press.

Boyd, M., and M. Vickers. 2000. 100 years of immigration in Canada. Canadian Social Trends. Catalogue no. 11-008.

Bumpass, L.L., and H. Lu. 2000. Trends in cohabitation and implications for children's family contexts in the United States. Population Studies 54(1):29-41. 
Bumpass, L.L., J.A. Sweet, and A. Cherlin. 1991. The role of cohabitation in declining rates of marriage. Journal of Marriage and Family 53(4):913-27.

Brown, S.L., J. Roebuck, and G.R. Lee. 2012. Transitions into and out of cohabitation in later life. Journal of Marriage and Family 74(4):774-93.

Dumas, J., and A. Belanger. 1997. Report on the Demographic Situation in Canada 1996. Cat. 91-209E. Ottawa: Statistics Canada.

Eggebeen, D., and J. Dew. 2009. The role of religion in adolescence for family formation in young adulthood. Journal of Marriage and Family 71:108-21.

ESDC (Employment and Social Development Canada). 2016. Family life - marriage. Indicators of Well-being in Canada. Accessed Feb 2016 from http://well-being.esdc.gc.ca/misme- iowb/.3ndic.1t.4r@-eng.jsp?iid=78.

Freedman, D., A. Thornton, D. Camburn, D. Alwin, and L. Young-DeMarco. 1988. The life history calendar: A technique for collecting retrospective data. Sociological Methodology 18:37-68.

Guzzo, K.B. 2014. Trends in cohabitation outcomes: Compositional changes and engagement among nevermarried young adults. Journal of Marriage and Family 76(4):826-42.

Hamplová, D., C. Le Bourdais, and É. Lapierre-Adamczyk. 2014. Is the cohabitation-marriage gap in money pooling universal? Journal of Marriage and Family 76:983-97.

Hassan, E. 2005. Recall bias can be a threat to retrospective and prospective research designs. The Internet Journal of Epidemiology 3(2).

Jenkins, S.P. 2005. Survival analysis. Institute for Social and Economic Research, University of Essex. Available online at http://www.iser.essex.ac.uk/survival-analysis.

Kerr, D., M. Moyser, and R. Beaujot. 2006. Marriage and cohabitation: Demographic and socioeconomic differences in Québec and Canada. Canadian Studies in Population 33(1):83-117.

Lapierre-Adamcyk, É., and C. Charvet. 2000. Cohabitation and marriage: An assesment of research in demography. Canadian Studies in Population 27(1):239-54.

Laplante, B. 2006. The rise of cohabitation in Quebec: Power of religion and power over religion. Canadian Journal of Sociology 31:2-24.

Laplante, B. 2014. Normative groups: The rise of the formation of the first union through cohabitation in Québec, A comparative approach. Population Research and Policy Review 33:257-85.

Le Bourdais, C., and É. Lapierre-Adamcyk. 2004. Changes in conjugal life in Canada: Is cohabitation progressively replacing marriage? Journal of Marriage and Family 66:929-42.

Lesthaeghe, R. 1995. The Second Demographic Transition in Western countries: An interpretation, in Gender and Family Change in Industrialized Countries, edited by K. Oppenheim Mason and A-M. Jensen. Oxford: Clarendon Press, p. 17-62.

Manning, W.D., and P.D. Smock. 2005. Measuring and modeling cohabitation: New perspectives from qualitative data. Journal of Marriage and Family 67:989-1002.

Manning, W.D., S.L. Brown, and K.K. Payne. 2014. Two decades of stability and change in age at first union formation. Journal of Marriage and Family 76:247-60.

Oppenheimer, V.K. 1997. Women's employment and the gain to marriage: The specialization and trading model. Annual Review of Sociology 23:431-53.

Pollard, M.S., and Z. Wu. 1998. Divergence of marriage patterns in Québec and elsewhere in Canada. Population and Development Review 24(2):329-56.

Rao, K.V. 1990. Marriage risks, cohabitation and premarital births in Canada. European Journal of Population 6:27-49. 
Ravanera, Z., F. Rajulton, and T.K. Burch. 1998. Early life transitions of Canadian women: A cohort analysis of timing, sequences, and variations. European Journal of Population 14: 179-204.

Ravanera, Z., F. Rajulton, T.K. Burch, and C. Le Bourdais. 2002. The early life courses of Canadian men: Analysis of timing and sequences of events. Canadian Studies in Population 29:293-312.

Sassler, S., and F. Goldscheider. 2004. Revisiting Jane Austen's theory of marriage timing: Changes in union formation among American men in the late 20th century. Journal of Family Issues 25(2):139-66.

Settersten, R.A., and B. Ray. 2010. What's going on with young people today? The long and twisting path to adulthood. The Future of Children 20(1):19-41.

Singer, J.D., and J.B. Willett. 2003. Applied Longitudinal Data Analysis: Modeling Change and Event Occurrence. New York: Oxford University Press.

Stanley, S.M., G.K. Rhoades, and H.J. Markman. 2006. Sliding versus deciding: Inertia and the premarital cohabitation effect. Family Relations 55:499-509.

Statistics Canada. 2012. Portrait of Families and Living Arrangements in Canada: Families, Households and Marital Status, 2011 Census of Population. Catalogue no. 98-312-X2011001. Ottawa: Statistics Canada.

Wu, Z. 2000. Cohabitation: An Alternative Form of Family Living. Don Mills, ON: Oxford University Press.

Wu, Z., and D.E. Baer. 1996. Attitudes toward family and gender roles: A comparison of English and French Canadian women. Journal of Comparative Family Studies 27:437-52.

Wu, Z., and T.R. Balakrishnan. 1995. Dissolution of premarital cohabitation in Canada. Demography 32(4):521-32.

Wu, Z., and M.S. Pollard. 2000. Economic circumstances and the stability of nonmarital cohabitation. Journal of Family Issues 21(3):303-28. 